\title{
Research on the Construction of Overseas China Law Library under "the Belt and Road" Background
}

\author{
Wei LIU \\ Planning Ministry, Zhongnan University of Economics and Law, Wuhan, China. \\ Distinct addresses: 182\# Nanhu Avenue, Wuhan 430073, P.R. China \\ E-mail:liuewei@foxmail.com
}

Keywords: China law library, the Belt and Road, legal culture, cultural self-confidence

\begin{abstract}
China law library is an important information security under "the Belt and Road" Background, it opens a window for the world to understand and perceive the legal culture of China. It is conducive to the dissemination and exchange of Chinese legal culture, and expand the international influence of the University.
\end{abstract}

\section{Introduction}

In January 13, 2017, "Sino - Italy Law Research Center" held a signing ceremony at the University of Roma La Sapienza. This is the first China Law Research Institute in Italy. At the same time," China Law Library" of the research center was unveiled. Zhongnan University of Economics and Law and Sapienza University of Rome cooperate in the construction of the "Sino - Italy Law Research Center". China is located at the eastern end of the Silk Road, Italy is located in the western end of the Silk Road, two countries have a high level foundation in cooperation and exchange .The two universities are the cradle of the famous jurist. The research center will become the most important platform for legal exchange between China and Italy. Through this platform, to promote scientific research, personnel training, teacher exchanges and other aspects of cooperation between two universities, especially to further promote the research and dissemination at the Rome law, Italy law and China method. China law library is the first overseas branch of library in Zhongnan University, located in Sapienza University of Rome, management by our library automation integrated system .The establishment of China law library is a great significance for Chinese culture to go out, spread Chinese legal culture and expand the influence of our university. The China law library will strive to become the largest China Law Library in Europe.

\section{“The Belt and Road" and Legal Culture Output}

"The Belt and Road" is the abbreviation of "The Silk Road Economic Belt and the 21st-Century Maritime Silk Road". "The Belt and Road " initiative become the new international strategy after the China participate in global governance of opening up to the world's second largest economy .It is an important opportunity to china to construct a new international order Under the background of globalization, informatization and networking, the new international cooperation relationship and the new international order.

The exchange of legal culture is an important part of the cultural exchanges along the ancient Silk Road. In the five legal systems in the world, there are three legal systems created by The Belt and Road along the country which about China law, India law and Islamic law. They shine in the evolutionary history of human law, and made great contributions to the development of world civilization. In the new historical situation, we need to further strengthen exchanges and cooperation in the field of law education .It is a continuation of the peoples of the important traditions of the Silk Road, and providing a solid legal protection and public opinion to promoting Belt and Road Initiative.

Cultural self-confidence is the full affirmation and positive practice for a nation, a country and a party of its own cultural value, and its cultural vitality of the firm confidence. In philosophy and 
Social Sciences forum held in May 17, 2016, the general secretary Xi Jinping mention the cultural self-confidence, and points out: "To strengthen theory confidence of the socialist road of China characteristic, confidence in the system, it is to strengthen cultural self-confidence. Cultural self-confidence is the cultural strength more and more profound, more durable." China Belt and Road" Initiative to build economic zone, to build a civilization has its own cultural circle, and the cultural sphere of "cultural power", in the end along the road must rise, as a cultural power emerged.

Through the law to carry out exchanges and cooperation, but also to exert influence, influence the legal system of other countries, It is an important way to participate in the formation of the international order." The Belt and Road" is the legal cooperation of the road, the road of foreign law. China law of cultural heterogeneity should be recognized and accepted by other countries and peoples of the world, do not wait for it, nor overnight, while the divergence of natural influence, It should also be through rational construction and promotion strategy to achieve."[1]With the continuous improvement of China's international status and the continuous improvement of the socialist legal system with China characteristics. In the process of foreign exchanges, we should actively export China legal concepts and values, legal system and the rule of law." Spreading the legal culture of socialism with Chinese characteristics with respect to country sovereignty and national culture, and actively spread the Chinese legal rules and method, spread out the sincerity of our law in developing countries, spread out our common destiny of legal consciousness, establish a 'rule of China' image."[2]

\section{The Establishment of Overseas Chinese Library}

Establishment of foreign cultural center is commonly used to culture of "going out" after World War II for the world's major countries .It is an important means of the publicity and promotion of national culture, the spread of ideological value idea, establish a good image of the country, is also an important platform to enhance cultural soft power.

The overseas Chinese Library in China is mainly composed of the overseas cultural center of the Ministry of culture. Since the establishment of the Chinese cultural center in Mauritius in 1988, the development of cultural centers abroad has gone through 26 years of. In 2015, the total number of overseas Chinese cultural centers reached 25[3] But the center book has the following drawbacks: foreign cultural exchanges and cultural center to introduce Chinese traditional culture lack of modern sense, the lack of future oriented depth of thinking content, therefore, the central library bibliography mainly in history, geography, literature, art, philosophy and religion, accounting for $50 \%$ of the books. There are lack of professional high intensive readings for the audience. See Table 1: 
Table 1 bibliographic classification of overseas Chinese Cultural Center Library [4]

\begin{tabular}{|c|c|c|c|}
\hline Serial number & category & Number & Proportion $(\%)$ \\
\hline 1 & History and geography & 885 & 17.70 \\
\hline 2 & literature & 710 & 14.20 \\
\hline 3 & Art & 619 & 12.38 \\
\hline 4 & Bilingual books & 537 & 10.74 \\
\hline 5 & Recommended reading & 315 & 6.30 \\
\hline 6 & Language and writing & 305 & 6.10 \\
\hline 7 & Philosophy, religion & 277 & 5.54 \\
\hline 8 & Politics and law & 250 & 5.00 \\
\hline 9 & Industrial Technology & 223 & 4.46 \\
\hline 10 & Bestseller & 176 & 3.52 \\
\hline 11 & Medical Science & 174 & 3.48 \\
\hline 12 & Award book & 160 & 3.20 \\
\hline 13 & $\begin{array}{c}\text { Culture, science, education } \\
\text { and sports }\end{array}$ & 101 & 2.02 \\
\hline 14 & Economics & 95 & 1.90 \\
\hline 15 & natural science & 76 & 1.52 \\
\hline 16 & Comprehensive book & 49 & 0.98 \\
\hline 17 & Reference book & 48 & 0.96 \\
\hline
\end{tabular}

In addition, the library collection of books of Chinese overseas theme "for historical research, collection of rich and colorful enough; and the need for recent researchers reliable data collection, a serious shortage of these areas, including business, law, politics, human rights, national security."[5]

\section{Apennine and Xixian Ridge [6]}

Italy is on the end of the ancient Silk Road, but also is the intersection of the maritime silk road. Whether it is across the Eurasian land on the sea or ocean, it is very popular in ancient Rome Empire.

The famous German jurist Ihering said: "Rome had three times to conquer the world, the first is by force ,the second is by religion, the third times is by law, and the third conquest is perhaps the most peaceful, most lasting for the conquest." The third conquest refers to the far-reaching influence of the Rome law on later generations. The concept of equality, justice and supremacy in Rome law has the eternal value beyond time, region and nation .It is on the basis of the comprehensive inheritance of the Rome law, which forms one of the two legal systems in the world today (the other is the Anglo American law system) also known as the Rome law or civil law system. The French civil code and the German civil code are the inheritance and development of the Rome law.

Since the reform in late Qing Dynasty, the legislation of our country has basically adopted the legislative framework of Rome law system. In 2014 the fourth Plenary Session of the 18th CPC Central Committee, the party's proposed codification. Therefore, the Rome law has great practical significance and normative value to the codification of contemporary Chinese civil code. Through this platform, to further promote research and the dissemination of Rome law, Italy law and China law, promote universities in scientific research, personnel training, teacher exchanges and cooperation.

The library is an important information security for the research center." China Law Library" contains law books, the domestic scholar's translation law works and foreign law books, outlines the 
picture of Chinese legal culture. The establishment of overseas China law library is of great significance for the Chinese culture to go out, to improve the soft power of the culture, to spread the Chinese legal culture and to enlarge the influence of our university.

A. China is playing an important role on the international stage, researchers pay more and more attention to china. Overseas readers to read Chinese books, help to understand complete and true china. This understanding is not limited to the imaginary mysterious traditional China, including the contemporary political, economic and social aspects of the face, as well as fresh and thought. The China law library has constructed the great power image of the modern rule of law in china.

B.to provide the necessary information for legal research. Our university cooperation based on professional configuration of sophisticated books, because the University intellectuals is community leaders, they recognize, analyze and solve reality problems and to learn and absorb, they have the right to speak, construction of public opinion.

C. Professional books represent the world level of China legal culture, and can fully and effectively express the China character and China logic of legal culture. To further enhance the academic and theoretical pertinence and persuasion of propaganda, and to improve the level of specialization.

D. the spread of China legal culture, democracy and the rule of law in China's image. Promote the output of China's soft power of law and expand the influence of the rule of law in china.

The library as a branch of zhongnan library, located at the University of Roma La Sapienza, since then, the Xixian golden sun will intersect with the Italy blue waves.

\section{The Construction of China Law Library}

In order to make China law library can be announced in January 2017, literature resources construction department of Zhongnan library is responsible for the organization, the reader service department, reference department and law school library cooperation, successfully completed the preparatory work. Allocation and procurement according to the Zhongnan University and the University of Roma La Sapienza jointly negotiated bibliography. First bibliography contains department law 、 legal history, history, politics and other 16 categories totaling more than 3000 books.

Various departments cooperate with each other, through the collection, retrieval books, supplemented by lack of book purchase allocation, finally to China Law Library collection. Through the efforts of various departments, completed a total of 1193 books of the deployment at the end of October, ensure the smooth open of China law library. The following books, from department of literature resources construction and law school library to complete the purchase, cataloging, collection and processing tasks, transported to Rome.

The law school organized journals such as "law research" "Law and Economic research", a total of 324 copies. The law school library also organized books 1163 volumes, including the "China law" and "jurisprudence", "civil law" "criminal law " ,a total of 888 copies.

Collection statistics of China Law Library:

A. 2356 books:

1. Tool book 108, including: Chinese law dictionary, English Chinese Dictionary of law, the new century French Dictionary, Anglo American Law Dictionary, Chinese dictionary.

2.37 volumes of foreign language books

3. Chinese legal professional books 2211.

B.1212 journals

In addition, the library of Zhongnan donated three IP of CNKI and 50 sets of scene bookmarks.

In the long run, the construction of China Law Library needs to consider the following points:

A. Establish regular updating mechanism. Regularly update and eliminate the literature, improve the quality of literature, adapt to the changes and development of the law.

B. Establish a reasonable source of funding for the acquisition of literature resources.

At present, the funds of the China law library are allocated by the Zhongnan library, and the 
funds for the activities and personnel training are not included in the annual budget of the library. It need recommended construction funds overseas library into the library funds, in addition to increase exchanges fund between the two

C. Actively explore literature resources cooperation.

D. Strengthen the construction of digital and $t$ new media resources.

E. The establishment of the book feedback mechanism, access to effective information, the formation of a complete information chain.

\section{Conclusion}

The establishment of China law library opens a window for the world to understand and perceive the legal culture of China. It is conducive to the spread and exchange of Chinese legal culture, and expand the international influence of the University. We should grasp the opportunity of foreign cultural development, expand the sources of funding, construct and allocate of document resources , supplemented by Internet、 digital media and other forms, introduces the research and the latest trends, promote the spread of China culture world-wide.

\section{References}

[1]LU Junjie, On the output of legal culture in the era of rule of law, Academic exploration (8) 2016.

[2]GU Zhaoming, On Legal Diplomacy, Doctoral Dissertation of Jilin University, 2015.P146.

[3] http://edu.sina.com.cn/a/2015-01-15/0811256774.shtml

[4] $]^{[\mathrm{WU}}$ Xueliang , Yu Feifei ,Thought on Literature Resources Construction and Configuration of Chinese cultural center libraries overseas, Journal of the National Library of China(6)2013.

[5]CAO Shule, Analysis on the collection of overseas libraries in China in recent years, Publishing wide-angle(9)2010.

[6]The Xixian ridge is nearby the library of Zhongnan University of Economics and Law. 